\title{
Size distribution, fatty acid composition and short-term storage studies on Blue mussel (Mytilus edulis) trochophores
}

\section{Mavi midye (Mytilus edulis) trokoforlarının boy dağılımı, yağ asit kompozisyonu ve kısa dönem canlı depolama çalışmaları}

\author{
Gamze Turan ${ }^{1 *}$ (D) - Linda J. Kling ${ }^{2}$ (iD \\ ${ }^{1}$ Ege University, Fisheries Faculty, Aquaculture Department, 35040 Bornova, Izmir, Turkey \\ 2 University of Maine, Department of Animal, Veterinary, and Aquatic Sciences, 04469 Orono, Maine USA \\ ${ }^{*}$ Corresponding author: gamze.turan@ege.edu.tr
}

Received date: 19.02 .2018

Accepted date: 02.05 .2018

How to cite this paper:

Turan, G. \& Kling, L.J. (2018). Size distribution, fatty acid composition and short-term storage studies on Blue mussel (Mytilus edulis) trochophores. Ege Journal of Fisheries and Aquatic Sciences, 35(3), 279-287. DOI:10.12714/egejfas.2018.35.3.07

\begin{abstract}
In this study, experiments were carried out to evaluate the blue mussel (Mytilus edulis) trochophore as a potential live feed for marine fish larvae. A short-term low temperature storage method has been developed to preserve and transport live trochophores. The mean size of $M$. edulis trochophores was found to be $73,50 \pm 5,24 \mathrm{mu}$. The survival rates of trochophores were ascertained in $4-5^{\circ} \mathrm{C}$ storage condition. Blue mussel fatty acid profile showed a predominance of 16: $0(14,17 \%)$ and 20: $5(\omega-3)(20,01 \%)$, and high concentrations of 16: $1(\omega-7)(7,79 \%)$ and 22: $6(\omega-3)(6,14 \%)$. Concentrations of 20: $5(\omega-3)$ and 22: $6(\omega-3)$ totaled $26,15 \%$. Total $\omega 3$-HUFA accounted for $36,14 \%$ of the total fatty acids. The study suggested that mussel trochophores would be a good diet for marine fish larvae due to the size, suitable fatty acid composition, storage time up to 6-7 days and also capability to swim at low temperatures.
\end{abstract}

Keywords: Blue mussel, trochophore, size, fatty acids, live storage

Öz: Bu çalışmada, mavi midye (Mytilus edulis) trokoforlarının deniz balı̆ı larvaları için potansiyel canlı yem kaynağı olarak değerlendirilmesi için deneyler gerçekleştirilmiştir. Canlı trokoforların kolay kullanımı ve taşınmaları için kısa dönem depolama metodu geliştirimiştir. Depolama koşullarında $\left(4-5^{\circ} \mathrm{C}\right)$ trokoforların yaşama yüzdeleri belirlenmiştir. Trokoforların ortalama boyu 73,50 $\pm 5,24 \mu$ m olarak ölçülmüşür. Yağ asit profilleri incelendiğinde 16: 1 (\%14,17) ve 20: 5 ( $\omega-3)$ $(\% 20,01)$ bakımından zengin olup, yüksek oranlarda da $16: 1(\omega-7)(\% 7,17)$ ve $22: 6(\omega-3)(\% 6,14)$ yağ asitterinin varlı̆̆ belirlenmiştir. $20: 5(\omega-3)$ ve $22: 6(\omega-3)$ konsantrasyonlarının toplamda \% 26,15 olduğu, $\omega$-3 HUFA' nın toplam yağ asitlerinin \% 36,14'ünü oluşturduğu saptanmıştır. Sonuç olarak midye trokforlarının büyüklüğü, uygun yağ asiti kompozisyonu, 6-7 güne kadar depolama süresi ve ayrıca düşük sıcaklıklarda yüzebilme yeteneği göstermelerinden dolayı deniz balıkları larvaları için iyi bir yem olacağı ön görülmektedir.

Anahtar kelimeler: Mavi midye, trokofor, boy, yağ asitleri, canlı depolama

\section{INTRODUCTION}

Feeding studies with several marine fish larvae have suggested that the $(\omega-3)$ HUFA content of the feed is a principal factor determining its dietary value (Sargent et al., 1989). Bivalve eggs and trochophores have a high percentage of 20: $5(\omega-3)$ and 22: $6(\omega-3)$ fatty acids (Pollero, 1979; Trider et al., 1980; Waldock et al., 1984; Beninger et al., 1985; Napolitano et al., 1992). Moreover, at certain times of the year bivalve larvae may be a part of the natural plankton assemblage which forms the natural diet of marine fish larvae. However, the use of bivalve trochophores as a potential food item for larval fish has not been adequately researched.

Only a few studies using fertilized eggs and trochophores as food sources have been reported. Benetti and Fagundes-
Netto (1982) reported that during production of larval mullet (Mugil liza), green water (between the $5^{\text {th }}$ day and throughout the culture period), fertilized oyster (Crassostrea brasiliana) eggs (between the $3^{\text {rd }}$ and $12^{\text {th }}$ days), rotifers (between the $5^{\text {th }}$ and $21^{\text {st }}$ days), and brine shrimp nauplii and metanauplii (after the $16^{\text {th }}$ day) were used. Survival rates at 6 months, indicated this feeding regime to be the best. Grouper larvae, (hybrid of white-spotted green grouper, Epinephelus amblycephalus, and wild red grouper, E. akaara) were sufficiently reared by feeding with fertilized oyster eggs, rotifers, and brine shrimp nauplii (Tseng and Poon, 1983). Similar results were also obtained for E. amblycephalus larvae fed fertilized oyster eggs, rotifers, and Artemia nauplii (Tseng and Chan, 1986) and milkfish (Chanos chanos) larvae fed with fertilized oyster eggs, rotifers, 
copepods, brine shrimp, flour and prepared feed, together with Chlorella (Liao et al., 1979).

By using natural plankton and nutritionally rich oyster trochophores as first food, Hawaiian stream goby (Lentimes concolor) larvae were reared successfully up to 21 days (Lindstrom, 1994). Hongchao and Feng (1990) determined that oyster trochophores were found to be the most suitable food item among the three kinds of live food sources (oyster trochophores, rotifers and Artemia nauplii) for the first feeding of black porgy (Sparus macrocephalus) larvae. Kentouri and Divanach (1986) reported that black mussel (Mytillus galloprovincialis) trochophores were treated as substitute prey by gilthead seabream (Sparus aurata) larvae. In addition, green mussel (Perna viridis) eggs and trochophores were considered to be the best potential live food source for greasy grouper (Epinephelus tauvina) larvae which cannot feed on S-type rotifers directly because of its small mouth size (Lim, 1991). The nutritional value of trochophores was illustrated in the study of Watanabe et al. (1996) who found that larval nassau grouper (Epinephelus striatus) fed a mixed-prey of $50 \%$ cryopreserved Crassostrea gigas trochophores and 50\% SS-type rotifers exhibited higher growth and survival than those fed rotifers or trochophores and rotifers in sequence.

Since trochophores develop from fertilized eggs in just a few hours and quickly develop into shelled veliger larvae, it is very unlikely that a sufficient number of trochophores could be produced to coincide exactly with the availability of initial feeding fish larvae. Thus, for eventual commercial development of marine fish culture, a means of holding and transporting live trochophores for "on demand" use at distant locations is needed. This need can be met by developing storage management techniques for bivalve trochophores. Storage of the trochophores below their culture or ambient temperature can be used to prolong their viability. The majority of relevant publications relate to storage of fish milt under chilled conditions, usually in domestic refrigerators (Stoss and Holtz, 1983; Scott and Baynes, 1980; McAndrew et al., 1993) Although fish ovaries can be successfully stored, most of the studies and applications of liquid storage of gametes relate to spermatozoa and to salmonids (Buyukhatipoglu and Holtz, 1978; Labbe et al., 2018; Paredes et al., 2012 and 2013; Stoss and Holtz, 1983; Scott and Baynes, 1980; McAndrew et al., 1993)

The main objective of the study is 1) to determine the sizes of the trochophores, 2) to investigate fatty acid composition of the trochophores, and 3) to establish the short-term storage methods to maximize trochophore survival.

\section{MATERIALS AND METHODS}

\section{Experimental animals}

Broodstock of blue mussel (Mytilus edulis) were obtained from different shellfish companies located along the eastern
Maine coast, Maine, USA (Table 1). Replications were determined by spawning dates for the broodstock and each replicate represents one batch of eggs from the mussel species spawned on a particular day. In grouping the blue mussel replications, egg colour was also considered a variable for both storage and fatty acid composition studies. During the spawning operations, orange, white, and mix (mix of white and orange) colored eggs were fertilized separately. The egg colours of M. edulis broodstock is shown in Table 2.

\section{Spawning operations}

Mussel broodstock was obtained from nature, and they were transported in a container packed in ice. These mussels were kept moist in a refrigerator at $4-6^{\circ} \mathrm{C}$ overnight. The next day, they were transferred into the spawning tank and filtered seawater $\left(22-24^{\circ} \mathrm{C}\right)$ was added to a depth of 5 to $6 \mathrm{~cm}$. The tank was drained and refilled continuously. When mussels started spawning, they were placed in containers of seawater to collect eggs and sperm separately. A small volume of sperm suspension (2-3 mL) was used to fertilize the 20 million eggs in the fertilization tank. Fifteen minutes after fertilization, a sample of eggs was checked under a microscope to determine fertilization success (Myrina et al., 2015). A compound microscope (Olympus) with 100x magnification was employed to determine developmental stages of the bivalve eggs, and measurements of the trochophore size and survival.

After $1 \mathrm{~h}$, developing embryos were collected on a $23 \mathrm{m \mu}$ mesh sieve, and placed into $150-\mathrm{mL}$ glass serum bottles (Myrina et al., 2015). They were then transported on ice to the laboratory and kept overnight in the refrigerator at $4{ }^{\circ} \mathrm{C}$ and were prepared for both fatty acid analysis and short-term storage studies. It was observed that 1 day after spawning, most of the embryos had reached the trochophore stage while in the refrigerator. They were moved from the refrigerator and left at room temperature (approximately $20^{\circ} \mathrm{C}$ ) for $15-30 \mathrm{~min}$. When the water temperature started to increase in the containers, viable trochophores started to swim into the upper part of the water column, while embryos remained at the bottom of the containers. The percentage of embryos that developed to trochophores was not examined. These embryos were removed from the containers by using a pipette. Mussel trochophores became mobile at $4{ }^{\circ} \mathrm{C}$, so the separation between $M$. edulis embryos and trochophores was performed without leaving the containers at room temperature.

\section{Size study}

The size of the trochophores was determined using a blood cell counter and a compound light microscope. Each replicate was mixed well, and a $1 \mathrm{~mL}$ sample was taken from each container with a pipette. A $1 \mathrm{~mL}$ sample was diluted in containers with $24 \mathrm{~mL}$ sea water, mixed well and a $1 \mathrm{~mL}$ subsample was used for size measurements. This step was repeated five times for each replicate. 
Table 1. Experimental M. edulis broodstock: replication number, source, and nutritional history

\begin{tabular}{llll}
\hline Species & Replicate & Source & Nutritional history \\
\hline M. edulis & 1 & Private Company I* & naturally-conditioned \\
M. edulis & 2 & Private Company I & naturally-conditioned \\
M. edulis & 3 & Private Company I & naturally-conditioned \\
M. edulis & 4 & Private Company II & naturally-conditioned \\
M. edulis & 5 & Private Company II & naturally-conditioned \\
M. edulis & 6 & Private Company II & naturally-conditioned \\
$M$. edulis & 7 & Private Company II & naturally-conditioned \\
$M$. edulis & 8 & Private Company II & naturally-conditioned \\
\hline
\end{tabular}

${ }^{*}$ GEMF: Great Eastern Mussel Farm, Long Cove Rd, Tenants Harbor, ME 04860, USA

${ }^{* *}$ Maine's Best Seafood, 61 Union St, Blue Hill, ME 04614, USA

Table 2. The experimental M. edulis broodstock species: replication number, spawned female and male number, and their egg colours

\begin{tabular}{lllll}
\hline Species & Replicate & $\begin{array}{l}\text { No } \\
\text { of female }\end{array}$ & $\begin{array}{l}\text { No } \\
\text { of male }\end{array}$ & egg colour \\
\hline M. edulis & 1 & $\mathrm{Nd}$ & $\mathrm{Nd}$ & Orange \\
M. edulis & 2 & $\mathrm{Nd}$ & $\mathrm{Nd}$ & Orange \\
M. edulis & 3 & 10 & 12 & Not specific \\
M. edulis & 4 & 6 & 8 & Orange \\
M. edulis & 5 & 5 & 8 & White \\
M. edulis & 6 & 7 & 7 & White \\
M. edulis & 7 & 8 & 7 & Orange \\
M. edulis & 8 & 15 & 7 & Not specific \\
\hline
\end{tabular}

Nd: Not determined, ${ }^{*}$ Not specific : mix of white and orange colour

\section{Fatty acid composition study}

\section{Sample preparation}

After embryos were removed from the containers, trochophore density was determined. A minimum of 0,5 million trochophores was added to each tube to provide sufficient lipid content for extraction and subsequent analysis. Using an average weight of $150 \mathrm{ng} /$ trochophore and a lipid concentration of $20 \%$ (Whyte et al., 1987), 0.5 million trochophores would provide approximately $15 \mathrm{mg}$ of lipid. Trochophores were collected on a $23 \mathrm{~m} \mu$ screen and rinsed with filtered seawater followed by ammonium formate solution $(3,2 \%$, w/v), in order to prevent oxidation of the lipids during storage (Whyte et al., 1991). They were then transferred into tapered test tubes, freeze-dried, and stored at $-80{ }^{\circ} \mathrm{C}$ until they were analyzed (Whyte et al., 1987).

\section{Total lipid extraction process}

The method described by Bligh and Dyer (1959) was used for lipid extraction. Moisture content of the samples was determined by drying overnight at $105^{\circ} \mathrm{C}$ in a laboratory oven (Stabil-Therm, Model OV500) and calculating the weight difference. In order to extract and purify all lipids from trochophores, chloroform-methanol (1:2) was added to the trochophore sample tubes at an amount equal to 3.75 times their water content, and mixed well. The mixture was kept for 30 minutes at room temperature and centrifuged at $2500 \mathrm{rpm}$ for 10 minutes in a refrigerated Sorvall RC-5B centrifuge. The supernatant, containing the lipid, was removed and stored. The remaining sedimented trochophore sample was re-extracted with 2-mL chloroform-methanol-water (1:2:0,8), mixed, and centrifuged. The second supernatant was combined with the first. The total volume of the extract was calculated. By dividing the total volume $(\mathrm{mL})$ by 3.75 , the amount of chloroform $(\mathrm{mL})$ added to the extract was calculated. Then, $2 \mathrm{M}$ (molar) potassium chlorate $(\mathrm{KCl})$ was added to the extract in the same amount of chloroform, and mixed well. At this point, two phases were observed. For exact separation of the phases, the mixture was left in the refrigerator overnight at $4{ }^{\circ} \mathrm{C}$. The upper phase was removed using a pipette. The lower phase, containing the lipid, was dried under nitrogen in a water bath (Nap Co., Model 202) at $45^{\circ} \mathrm{C}$. One $\mathrm{ml}$ chloroform was added to the dried tubes and the mixture was filtered through a glass funnel packed with glass wool into a weighed round-bottom tube to remove any undissolved material. The procedure was repeated with the addition of $1 \mathrm{~mL}$ of chloroform, and the filter was washed with $1 \mathrm{~mL}$ chloroform to wash out the lipid. The filtered extract was dried under nitrogen for 15 minutes and the tube was weighed. For $10 \mathrm{mg}$ extract, $1 \mathrm{~mL}$ chloroform with $0.005 \% \mathrm{BHT}$ (butylated hydroxy-toluene) was added to the dried extract just before the storage of the lipid sample in the freezer at $-20^{\circ} \mathrm{C}$ (Bligh and Dyer, 1959).

In the third step (transesterification), a $30 \mu \mathrm{L}$ sample was taken from the stored lipid sample solution and placed into a tapered tube. The sample was dried under nitrogen in a water bath. First, $0,5 \mathrm{~mL}$ toluene then $0,5 \mathrm{~mL}$ metabolic base reagent (Alltech, Inc.) were added into the dried tube. After it was mixed well, the tube was placed in a Lab-Line multi-block heater at 70$80^{\circ} \mathrm{C}$ for $15-20$ minutes. The mixture was then allowed to cool to room temperature, and $1,5 \mathrm{~mL}$ of distilled water and $1,5 \mathrm{~mL}$ 
methylene chloride were added to the tube. The mixture was capped and mixed well. At this point the sample was stored in the freezer at $-20{ }^{\circ} \mathrm{C}$ to separate the phases prior to gas chromatographic analysis (Bligh and Dyer, 1959).

A Gas Chromatograph (Hewlett Packard, Model 5890A), fitted with a capillary inlet system, a flame ionization detector, and connected to an integrator (Hewlett Packard, Model 3390A), was used for the analysis. The fatty acid methyl esters were separated on a Supelcowax 10 fused silica capillary column (30x 0,32 $\mathrm{mm} \mathrm{ID}, 0,25 \mathrm{~m}$ film) programmed to $160^{\circ} \mathrm{C}$ with a $3^{\circ} \mathrm{C} / \mathrm{min}$ rise in the column temperature and held at 262 ${ }^{\circ} \mathrm{C}$ for 6 min. Both injection and detector temperatures were maintained at $250{ }^{\circ} \mathrm{C}$. Helium carrier gas was purified through a high capacity heated gas purifier (Supelco, Inc.) and controlled at a linear velocity of $40 \mathrm{~mL} / \mathrm{min}$ with a split ratio of 25:1. Analyte solutions (1-2 $\mathrm{mL}$ ) were separated and identified by comparison with standard (cod liver oil) (Dr. Desiervo, pers. comm.). The integrator was programmed to reject areas less than 1000 and peak widths less than 0,04 min for noise rejection and peak recognition.

\section{Short-term storage conditions and survival measurements}

After embryos were removed from the spawning buckets, trochophores were stored in $150 \mathrm{~mL}$ containers at a density of 2500 individuals $/ \mathrm{mL}$, and they were transported from Rogers Hall, University of Maine to the Darling Marine Center, University of Maine, where short-term storage studies were conducted. The containers were placed in the refrigerator at a constant temperature of 4 to $5{ }^{\circ} \mathrm{C}$. According to the second preliminary experiment, $4^{\circ} \mathrm{C}$ was found to be the best for shortterm storage because at that temperature, development beyond the trochophore stage does not occur in $M$. edulis. In order to reduce the bacterial growth in the containers, $1000 \mathrm{IU}$ penicillin, $100 \mu \mathrm{g}$ streptomycin and $500 \mu \mathrm{g}$ neomycin were added to each milliliter trochophore suspension. Kanamycin $(100 \mu \mathrm{g} / \mathrm{mL})$ was used to replace neomycin during the last two months of the experiment (Dr. Opitz, pers. comm.). Every other day, filtered (0.22 $\mathrm{m \mu}$ mesh size) seawater was removed and replaced with $100 \mathrm{~mL}$ oxygen- rich seawater for the trochophore larvae.

The survival of the trochophores was determined daily. Each trochophore suspension was thoroughly mixed, and a 1 $\mathrm{mL}$ sample was taken from each container with a pipette and placed in a blood cell counter. The number of live and dead trochophores was observed under 100x magnification and recorded. This procedure was repeated five times for each sample. The short-term storage experiments were stopped when the survival rate of trochophores was $0 \%$. The storage period varied from 4 to 19 days.

During the storage experiments, salinity was measured with a hand-held refractometer (Atagor C., Ltd., Model 2441-W05) Dissolved oxygen levels (ppt) in the containers were measured with a Sentry III Oxygen/ Temperature Monitor (Otterbine,
Bartbo, Inc.). A pocket size ATC pH Tester (Cole Parmer, Model 59000-20) was used to measure $\mathrm{pH}$.

\section{Statistical analysis}

Size and fatty acid composition data were analyzed using the MEAN Procedure using SAS (SAS Institute Inc., 1990). All data were expressed as means standard deviation. Survival data were analyzed using the LIFETEST Procedure with Logrank Test described by SAS (SAS Institute Inc., 1990). The logrank method has been used for biological data that compare survival rate among patients who received different treatments, or physical data that compare the lifetime of different diesel engines. The Logrank test compares the survival period using the Chi-square statistic. This method has several advantages over the other methods such as analysis of variance (ANOVA) and GLM. The Logrank fits nonparametric data, uses all data during the experimental period instead of a fixed time period, and it can analyze incomplete data. The LIFETEST procedure provided product-limit or life table estimates (day, with median survival period (days to $50 \%$ survival) standard error), and linear rank statistics using either Wilcoxon or log-rank scores.

\section{RESULTS AND DISCUSSION}

\section{Size of trochophores}

Mean size of mussel trochophores recorded here as $73.50 \pm 5.24 \mathrm{~m} \mu$ is similar to that found previously (Bayne, 1976; and $C$. Lantaigne, unpublished results). Trochophores of $M$. edulis are 70-110 $\mathrm{m} \mu$ in size (Bayne, 1976). C. Lantaigne (unpublished results) also found that $M$. edulis trochophores were 81-711 $\mathrm{m} \mu$ in size.

The importance of prey size to successful first feeding of larval nassau grouper (E. striatus) was demonstrated previously (Watanabe et al., 1996). Watanabe et al. (1996) concluded that crypreserved $C$. gigas trochophores (mean diameter $=49,9 \mathrm{~m} \mu$; range $=35-60 \mathrm{~m} \mu$ ), although insufficient when used alone, resulted in improved survival of larval $E$. striatus when used in combination with S-type rotifers, Hawaiian strain, (mean lorica length $=161 \mathrm{~m} \mu$; range $=74-264$ $\mathrm{m \mu}$ ) and SS-type rotifers, Thai strain, (mean lorica length $=147$ $\mathrm{m} \mu$; range $=67-237 \mathrm{m \mu}$ ). Using a mix prey regime allowed greater percentage of the larvae at the time of mouth opening to ingest $C$. gigas trochophores probably related to the small size and low motility of $C$. gigas trochophores (Watanabe et al., 1996).

Based on size, M. edulis trochophores would be best prey item for cod or similar size fish larvae. Previous studies show that the prey size for Pacific cod larvae at $5 \mathrm{~mm}$ total length ranged between $67.5 \mathrm{~m} \mu$ and $129 \mathrm{m \mu}$ (Takatsu et al., 1995).

\section{Fatty acid composition of trochophores}

The fatty acid profiles (\%, mean \pm standard deviation) of the $M$. edulis trochophores are presented in Table 3. Results show that the fatty acids of $16: 0 ; 16: 1(\omega-7) ; 18: 0 ; 18: 1(\omega-$ 9); 20: $5(\omega-3)$; as well as 22: $6(\omega-3)$ are, in general, the major 
constituents (Table 3 ). The M. edulis fatty acid profile showed a predominance of 16: $0(14,2 \%)$ and $20: 5(\omega-3)(20 \%)$, and high concentrations of $16: 1(\omega-7)(7,8 \%)$ and $22: 6(\omega-3)(6 \%)$. Concentrations of 20: $5(\omega-3)$ and 22: $6(\omega-3)$ totaled $26.2 \%$ Total $\omega-3$ HUFA accounted for $36,1 \%$ of the total fatty acids. This result reflects a major characteristic of the marine food web where unicellular algae of phytoplankton are the primary producers and they contain approximately $20 \%$ of their dry weight as polar lipids, of which about $50 \%$ is the $\omega-3$ series HUFA. The $\omega-3$ HUFA in the phytoplankton is accumulated in the tissues of primary consumers such as zooplankton, bivalves and zooplanktivorus fish (Sargent et al., 1989). Most fish species require $\omega-3$ HUFAs. Their tissues contain predominantly HUFAs of the $\omega-3$ series rather than the $\omega-6$ series. In fact, 20: $5(\omega-3)$ and 22: $6(\omega-3)$ are the major HUFAs of fish, whereas linoleic acid, 18: 2 ( $\omega-6)$, and arachidonic acid, 20: $4(\omega-6)$, are the major HUFAs of land animals. For most fish species, this specific requirement reflects a major characteristic of the aquatic environment where relatively low and constant temperatures occur (Sargent et al., 1989). The high level of 20 $5(\omega-3)(20 \%)$ and 22: $6(\omega-3)(6 \%)$ were found in M. edulis. These results support the conclusions obtained previously that bivalve eggs and trochophores have high levels of essential fatty acids in their lipids (Pollero, 1979; Trider et al., 1980 Waldock and Holland, 1984; Beninger and Stephan, 1985; and Napolitano et al., 1992). A comparison of the fatty acid composition of bivalve trochophores found in the present study with that of previous studies revealed differences in 20: $5(\omega-3)$ and 22: $6(\omega-3)$ compositions (Table 5). The dissimilarities of essential fatty acid composition among the bivalve species may be due to taxonomic differences, or differences in the diets of the parents. Watanabe and Ackman (1974) also found species specific fatty acid composition of $C$. virginica and $O$. edulis. $M$. edulis trochophores from different sources have different fatty acid profiles (Table 4). In the present study 20: $5(\omega-3)$ and 22 : $6(\omega-3)$ of $M$. edulis trochophores were found to be $20.01 \%$ and $6,14 \%$, respectively. In previous studies, the values were $1,74 \%$ and $40,5 \%$ (J.N.C. Whyte, unpublished results), 18,85 $\%$ and $13 \%$ (C. Lantaigne, unpublished results), and 9,27\% and $10 \%$ (C. Lantaigne, unpublished results), respectively. These differences in essential fatty acid composition of $M$. edulis trochophores supports conclusions obtained previously by Sastry (1979), Bayne et al. ( 1975), Bayne et al. (1978), Gallager and Mann (1986), Pollero et al. (1979), Trider et al. (1980), Waldock and Holland (1984), Beninger and Stephan
(1985), and Napolitano et al. (1992). These studies found that endogenous lipid reserves and fatty acid composition of bivalve eggs and trochophores are dependent on the nutritional status of the female parents.

Table 3. The fatty acids (\%, mean \pm standard deviation) of $M$. edulis trochophores

\begin{tabular}{|c|c|}
\hline Fatty acids & M. edulis $(\mathrm{N}=8)$ \\
\hline $14: 0$ & $1,129 \pm 0,828$ \\
\hline 14: 1 & $0,075 \pm 0,131$ \\
\hline 15: 0 & $1,171 \pm 0,206$ \\
\hline 16: 0 & $14,165 \pm 3,661$ \\
\hline 16: $1(\omega-9)$ & $0,000 \pm 0,000$ \\
\hline 16: $1(\omega-7)$ & $7,793 \pm 3,288$ \\
\hline 16: $1(\omega-5)$ & $0,156 \pm 0,297$ \\
\hline $17: 0$ & $0,346 \pm 0,144$ \\
\hline $17: 1$ & $0,131 \pm 0,144$ \\
\hline 18: 0 & $3,206 \pm 0,806$ \\
\hline 18: $1(\omega-9)$ & $2,597 \pm 0,768$ \\
\hline 18: $1(\omega-7)$ & $2,701 \pm 0,857$ \\
\hline 18: $1(\omega-5)$ & $0,066 \pm 0,093$ \\
\hline 18: $2(\omega-6)$ & $1,209 \pm 0,697$ \\
\hline 18: $3(\omega-3)$ & $0.634 \pm 0.291$ \\
\hline 18: $4(\omega-3)$ & $2,667 \pm 1,115$ \\
\hline 20: 0 & $0,171 \pm 0,418$ \\
\hline 20: $1(\omega-11)$ & $1,623 \pm 0,496$ \\
\hline 20: $1(\omega-9)$ & $2,703 \pm 0,905$ \\
\hline 20: $1(\omega-7)$ & $1,884 \pm 0,692$ \\
\hline $20: 2(\omega-6)$ & $0,793 \pm 0,896$ \\
\hline 20: $3(\omega-6)$ & $0,314 \pm 0,339$ \\
\hline $20: 4(\omega-6)$ & $1,576 \pm 0,340$ \\
\hline 20: $3(\omega-3)$ & $0,833 \pm 1,430$ \\
\hline $20: 4(\omega-3)$ & $3,922 \pm 8,154$ \\
\hline 20: $5(\omega-3)$ & $20,008 \pm 6,249$ \\
\hline 22: $1(\omega-11)$ & $3,261 \pm 5,634$ \\
\hline $22: 1(\omega-9)$ & $0,085 \pm 0,224$ \\
\hline 22: $1(\omega-7)$ & $0,031 \pm 0,082$ \\
\hline $21: 5(\omega-3)$ & $0,835 \pm 0,301$ \\
\hline 22: $4(\omega-6)$ & $0,200 \pm 0,269$ \\
\hline 22: $5(\omega-6)$ & $0,376 \pm 0,994$ \\
\hline $22: 5(\omega-3)$ & $1,330 \pm 0,585$ \\
\hline $22: 6(\omega-3)$ & $6,137 \pm 2,573$ \\
\hline$\sum(\omega-3)$ HUFA & $36,135 \pm 5,774$ \\
\hline$\sum(\omega-6)$ HUFA & $4,345 \pm 2,508$ \\
\hline$(\omega-3) /(\omega-6)$ & $10,482 \pm 4,871$ \\
\hline$\sum$ HUFA & $40,700 \pm 6,609$ \\
\hline 20: $5(\omega-3) / 22: 6(\omega-3)$ & $3,376 \pm 0,447$ \\
\hline
\end{tabular}

Table 4. Essential fatty acid (\%) composition of living organisms

\begin{tabular}{llllll}
\hline Species & Sorce & $\mathbf{2 0 : 5}(\omega-\mathbf{3})$ & $\mathbf{2 2 : 6 ( \omega - 3 )}$ & $\sum(\omega-3)$ Hufa & References $^{*}$ \\
\hline C. gigas & From nature & 15,59 & 13,5 & 41,41 & J.N.C. Whyte \\
M. edulis & From nature & $\mathbf{2 0 , 0 1}$ & $\mathbf{6 , 1 4}$ & $\mathbf{3 6 , 1 4}$ & Present \\
M. edulis & From nature & 18,85 & 13 & $\mathrm{~Np}{ }^{* *}$ & C. Lantaigne \\
M. edulis & I. galbana & 9,27 & 10 & $\mathrm{~Np}$ & C. Lantaigne \\
M. edulis & $\mathrm{Np}$ & 1,74 & 40,5 & $\mathrm{~Np}$ & J.N.C. Whyte \\
M. merceneria & $\mathrm{Np}$ & 0,72 & 27,6 & $\mathrm{~Np}$ & J.N.C Whyte \\
\hline
\end{tabular}




\begin{tabular}{|c|c|c|c|c|c|}
\hline M. merceneria & $\mathrm{Np}$ & 11,2 & 10,2 & $\mathrm{~Np}$ & C. Lantaigne \\
\hline S. solidissima & $\mathrm{Np}$ & 13,5 & 11,2 & $\mathrm{~Np}$ & C. Lantaigne \\
\hline B. plicatilis & I. galbana & 3,06 & 5 & $\mathrm{~Np}$ & C. Lantaigne \\
\hline B. plicatilis & $\omega$-yeast & $9-12$ & $7-9$ & $25-26$ & Watanabe et al. (1983) \\
\hline I. galbana & $\mathrm{Np}$ & 4,6 & 10,7 & $\mathrm{~Np}$ & C. Lantaigne \\
\hline I. galbana & $\mathrm{Np}$ & 2,21 & 25,85 & $\mathrm{~Np}$ & J.N.C. Whyte \\
\hline C. gracilis & $\mathrm{Np}$ & 10,24 & 1,2 & $\mathrm{~Np}$ & C. Lantaigne \\
\hline C. gracilis & $\mathrm{Np}$ & 33,71 & 1,84 & $\mathrm{~Np}$ & J.N.C. Whyte \\
\hline Pavlova lutheri & $\mathrm{Np}$ & 28,6 & 13,7 & $\mathrm{~Np}$ & C. Lantaigne \\
\hline A. salina & Super selco & 10,2 & 7,5 & $\mathrm{~Np}$ & Stottrup and Attramadal (1992) \\
\hline Acartia clause & From nature & 29,2 & 27,2 & 58 & Watanabe et al. (1983) \\
\hline T. japonicus & S-yeast & 10,8 & 13,6 & 26,6 & Watanabe et al. (1983) \\
\hline Moina sp. & Poultry manure & 20,8 & $\operatorname{tr}^{* \star *}$ & 21,5 & Watanabe et al. (1983) \\
\hline Daphnia sp. & $\mathrm{Np}$ & 16,5 & 0,2 & $\mathrm{~Np}$ & Watanabe et al. (1983) \\
\hline
\end{tabular}

The comparison of fatty acid composition between living organisms such as B. plicatilis, A. salina, and trochophores shows that trochophores are very rich in essential fatty acids. Thus they have high nutritional value to larval fish. The concentrations of 20: $5(\omega-3)$ and 22: $6(\omega-3)$ in the trochophores are as high as the values that were found in enriched B. plicatilis and $A$. salina. For example, in the present study, 20: $5(\omega-3)$ level was 20,01\% in M. edulis trochophores. This amount is higher than those found in enriched $B$. plicatilis $(9,12 \%)$ and in $A$. salina $(10,2 \%)$. These results suggest that using individual or combined trochophore mixed diet can supply the same or higher level of essential fatty acids than those commonly used for feeding of marine fish larvae.

A number of factors should be avoided in future experiments. The fatty acid composition studies should be conducted only on bivalve trochophores whose parents received the same diet. This will allow detection of species specific fatty acid compositions. The fatty acid composition of the broodstock diet should also be taken into account when evaluating the trochophore fatty acid profiles to reduce the variation in fatty acids.

Based on fatty acid content and composition, M. edulis trochophores would be best prey items for cod, haddock, flounder, snapper, grouper, red drum, black drum, and black sea bass larvae due to their rich 20: $5(\omega-3), 22: 6(\omega-3)$, and total $(\omega-3)$ HUFA contents.

\section{Short-term storage of trochophores}

The survival curves of the trochophores and the median survival periods (days, with median \pm standard errors) of the trochophores during storage at $4-5^{\circ} \mathrm{C}$ are presented in Table 5 . At a temperature of $4-5{ }^{\circ} \mathrm{C}$, survival of the trochophores decreased with increasing length of storage. The median survival period, $\mathrm{LD}_{50}$, (days, with standard error) for the stored M. edulis trochophores was found to be $6,6 \pm 0,2$ days at $50 \%$ survival.

Table 5. Median survival period (days, with median \pm standard errors) of $M$. edulis trochophores during the short-term storage period at $4-5^{\circ} \mathrm{C}$

\begin{tabular}{lll}
\hline Day & $\begin{array}{l}\text { Survival }(\%) \text { of } \\
\text { M. edulis }(\mathbf{N}=6)\end{array}$ & Std. error \\
\hline 0 & 94,94 & 0,0110 \\
1 & 87,34 & 0,0167 \\
2 & 81,01 & 0,0197 \\
3 & 73,42 & 0,0222 \\
4 & 65,82 & 0,0239 \\
5 & 58,23 & 0,0248 \\
6 & 50,63 & 0,0252 \\
7 & 43,04 & 0,0249 \\
8 & 35,44 & 0,0241 \\
9 & 27,85 & 0,0226 \\
10 & 20,25 & 0,0202 \\
11 & 12,66 & 0,0167 \\
12 & 07,59 & 0,0133 \\
13 & 03,80 & 0,00962 \\
14 & 01,27 & 0,00562 \\
15 & 0 & 0 \\
16 & 0 & 0 \\
17 & 0 & 0 \\
18 & 0 & 0 \\
\hline
\end{tabular}




\begin{tabular}{lll}
\hline 19 & 0 & 0 \\
& Day & Std. Error \\
$\mathrm{MSP}^{*}$ & 6.6354 & 0.2012 \\
\hline
\end{tabular}

${ }^{*}$ Median survival period at $50 \%$ survival $\left(\mathrm{LD}_{50}\right)$

Table 6. Water quality parameters (with mean \pm standard deviation and range) during storage at $4-5^{\circ} \mathrm{C}(\mathrm{N}=125)$

\begin{tabular}{llll}
\hline $\begin{array}{l}\text { Water quality } \\
\text { parameters }\end{array}$ & Mean & $\begin{array}{l}\text { Standard } \\
\text { deviation }\end{array}$ & Range \\
\hline Temperature $\left({ }^{\circ} \mathrm{C}\right)$ & 4,83 & 0,25 & $4-5$ \\
Oxygen $(\mathrm{ppm})$ & 8,09 & 0,38 & $6,8-8,8$ \\
$\mathrm{PH}$ & 7,74 & 0,16 & $7,5-8,5$ \\
Salinity (ppt) & 30,89 & 0,17 & $30-32$ \\
\hline
\end{tabular}

Water quality parameters during the storage experiment, as shown in Table 6, were within the tolerable range for bivalve eggs and larvae (Lough, 1975; Davis and Calabrese, 1964; and Bayne,1976). Water temperature varied from 4 to $5{ }^{\circ} \mathrm{C}$ Dissolved oxygen ranged from 6,8 to $8,8 \mathrm{ppm}$. $\mathrm{PH}$ varied from 7,5 to 8,5 . Salinity was between 30 and 32 ppt.

There are several different areas which warrant further investigation: (a) the depletion of the endogenous lipid stores of the bivalve trochophores during storage, (b) the use of cryoprotectants such as sucrose and methanol during the storage period and their effects on survival of trochophores, (c) the use of the antibiotics such as penicillin and streptomycin during the storage and their effects on bacterial growth in the containers and (d) preparing different trochophore products such as, freezed, freezed dried trochophores and their fatty acid composition quality and performance in the feeding of fish larvae.

\section{CONCLUSION}

The literature supports the importance of prey size for first feeding of larval fish (Watanabe et al., 1996). The size of the trochophores found $(M$. edulis $(73,50 \mathrm{m \mu}))$ in this study were similar to those obtained previously (Galtsoff, 1964; Kennedy et al., 1995; Broom, 1976; Loosanoff and Davis, 1963; Bayne, 1976; and C. Lantaigne, unpublished results). In future studies, suitability of the trochophore size should be tested for fish larvae in order to evaluate feeding potential of trochophores. $M$. edulis trochophore would be considered a good prey item for cod, G. morhua, larvae because previous study shows that the prey size for Pacific cod, G. macrocephalus, larvae in $5 \mathrm{~mm}$ total length varied between $67,5 \mathrm{~m} \mu$ and $129 \mathrm{~m} \mu$ (Takatsu et al., 1995). M. edulis trochophores could be used for rearing operations of larval mullet, groupers, milkfish, goby, red drum, black sea bream, and gilthead bream larvae (Bennetti and Fagundes-Netto, 1982; Tseng and Poon, 1983; Tseng and Chan, 1986; Lindstrom, 1994; Hongchao and Feng, 1990; Kentouri and Divanach, 1986; Lim, 1991; Pickering and Holt, 1993; and Watanabe et al., 1996). Although, size is the major factor for determining prey selectivity, the other important factors such as prey visibility, and speed also play important roles and should be considered.
The nutritional qualities (mainly, 20: $5(\omega-3)$ and 22: 6 ( $\omega$ 3)) of $M$. edulis trochophores were presented in this study. A high level $(20,01 \%)$ of $20: 5(\omega-3)$ and a high level $(6,14 \%)$ of 22: $6(\omega-3)$ were found in the M. edulis trochophores. The study of fatty acid composition of $M$. edulis trochophores revealed in the present study supports previous work showing that bivalve eggs and trochophores have a high ratio of essential fatty acids in their lipids (Pollero et al., 1979; Trider et al., 1980; Waldock and Holland 1984; Beninger and Stephan, 1985; Whyte et al., 1990 and 1991). Thus trochophores of $M$. edulis have high potential as a food source for fish larvae. M. edulis trochophores would be the best diet for cold water marine fish larvae because of their ability to swim at low temperature (4-5 $\left.{ }^{\circ} \mathrm{C}\right)$, their high essential fatty acid composition, their larger size, their possible storage and transportation period up to 6,6 days.

The survival of bivalve trochophores during storage was facilitated by the maintenance of a relatively low temperature $\left(4-5{ }^{\circ} \mathrm{C}\right)$, using antibiotics, and fresh filtered seawater. The median survival periods were found to be 6,6 days for $M$. edulis trochophores. Evidence for a period of delayed development during cold storage was provided by the results of this study. The trochophores stored at $4-5{ }^{\circ} \mathrm{C}$ did not develop to the Dlarval stage (Joyce and Vogeler, 2018). The procedures followed in this experiment hold the possibility of reducing larval development of the bivalves at the trochophore stage and keeping them for 5-7 days at $4-5^{\circ} \mathrm{C}$. Cryoprotectants such as sucrose or methanol were not used in this study. The bacterial growth in the containers was not examined, however antibiotics were employed. Besides water quality and bacterial growth, lipid reserves in eggs and trochophores could greatly affect their survival (Bayne et al., 1978; Gallager and Mann, 1986; Huo, et al., 2017). Bayne et al. (1978) stated that less lipid being apportioned to each egg causes a reduction in larval survival. Until more is learned about the factors affecting survival of trochophores during low temperature storage, the method tested in this study appears suitable for short-term storage of trochophores.

The storage procedure could be used in commercial aquaculture operations which require holding and transporting live trochophores up to 5-7 days. The successful results could bring benefits to both marine fish producers who want to use 
trochophores for first feeding of fish larvae, and shellfish producers who wants to market their trochophores.

\section{ACKNOWLEDGMENTS}

Authors thank to the Turkish Republic Ministry of Education for providing funding for this study which is a part of thesis study of Master of Science through a grant for corresponding author to pursue her Master Degree in the USA. The authors are also thankfull to Dr. Desiervo for fatty acid analysis, Dr. C. Lantaigne and Dr. John Catell for sharing their unpublished data on mussel throchophores and fatty acid composition of living organisms and Dr. Opitz for the preparation of sterile seawater for storage studies.

\section{REFERENCES}

Bayne, B.L. (1976) The biology of mussel larvae. In Marine Mussels: Their Ecology and Physiology. B.L. Bayne (ed), Cambridge University Press, Cambridge, pp: 81-120.

Bayne, B.L., Gabbott, P.A. \& Widdows, J. (1975) Some effects of stress in the adult on the eggs and larvae of Mytilus edulis L. Journal of Marine Biological Association of the United Kingdom, 55:675-689. DOI: 10.1017/S0025315400017343

Bayne, B.L., Holland, D.L., Moore, M. N., Lowe, D.M. \& Widdows, J. (1978) Further Studies on the effects of stress in the adult on the eggs of Mytilus edulis. Journal of Marine Biological Association of the United Kingdom, 58:825-841. DOI: $10.1017 /$ S0025315400056794

Benetti, D. \& Fagundes-Netto, E. (1982) Production of mullet's fingerlings (Pisces, Mugilidae) in laboratory. Atlantica, 5, No 2, $14 \mathrm{p}$

Beninger, P.G. \& Stephan, G. (1985) Seasonal variations in the fatty acids of the triacylglycerols and phospholipids of two populations of adult clams (Tapes decussatus and Tapes phillipinarum) reared in a common habitat. Comparative Biochemistry and Physiology, 81B: 591-601. DOI: $10.1016 / 0305-0491(85) 90372-4$

Bligh, E.G. \& Dyer, W.J. (1959) A rapid method of total lipid extraction and purification. Canadian Journal of Biochemistry and Physiology, 37: 911 917. DOI: 10.1139/059-099

Broom, M.J. (1976) Synopsis of biological data on scallops. FAO Fisheries Synopsis No 114. (FIRS/S114). 43 p

Buyukhatipoglu, B. \& Holtz, W. (1978) Preservation of trout sperm in liquid or frozen state. Aquaculture, 14: 49-56 DOI: 10.1016/0044-8486(78)90139-4

Davis, H.C. \& Calabrese, A. (1964) Combined effects of temperature and salinity on development of eggs and growth of larvae of $M$. mercenaria and C. virginica. Fishery Bulletin of the Fish and Wildlife Service of United States, 63, pp. 643-655.

Gallager, S.M. \& Mann, R. (1986) Growth and survival of larvae of Mercenaria mercenaria L. and Crassosterea virginica Gmelin relative to broodstock conditioning and lipid Content of eggs. Aquaculture, 56: 105-121. DOI: 10.1016/0044-8486(86)90021-9

Galtsoff, P.S. (1964) The American oyster Crassostrea virginica Gmelin. Fishery Bulletin, 64: 1-480.

Hongchao, R. \& Feng, Y. (1990) Feeding selectivity of artificially-reared black porgy larvae Sparus macrocephalus. Advances in Marine Science Haiyang Kexue, 6: 39-41.

Huo, Z., Guan, H., Golam Rbbani, M., Xiau, Y., Zhang, X., Fan, C., Li, Z., Li, Y., Wu, Q., Yang, F. \& Yan, X. (2017). Effects of environmental factors on growth, survival, and metamorphosis of geoduck clam (Panopea japonica A. Adams, 1850) larvae, Aquaculture Reports, 8: 31-38. DOI: 10.1016/j.aqrep.2017.09.001

Joyce, A. \& Vogeler, S. (2018). Molluscan bivalve settlement and metamorphosis: Neuroendocrine inducers and morphogenetic responses. Aquaculture, 487:64-82. DOI:10.1016/j.aquaculture.2018.01.002

Kennedy, V.S., Newell, R.I.E., Krantz, G.E. \& Otto, S. (1995) Reproductive capacity of the eastern oyster Crassostrea virginica infected with parasite Perkinsus marinus. Diseases of Aquatic Organisms, 23: 135-144.

Kentouri, M. \& Divanach, P. (1986) Food range of sparid larvae in controlled conditions Specific selectivity of Sparus aurata. Oceanologica Acta, 9 343-348.

Labbe, C., Haffray, P., Mingant, C., Quittet, B., Diss, B., Adams, S.L., Rimond, F. \& Suquet, M. (2018). Cryopreservation of Pacific oyster (Crassostrea gigas) larvae: Revisiting the practical limitations and scaling up the procedure for application to hatchery, Aquaculture, (In Press).

DOI: 10.1016/j.aquaculture.2018.01.023

Liao, I.C., Juario, J.V., Kumagai, S. Nakajima, H. \& Natividad, M. (1979) On the induced spawning and larval rearing of milkfish, Chanos chanos Forskal. Aquaculture, 18:75-93. DOI: 10.1016/0044-8486(79)90021-8

Lim, L.C. (1991) Larviculture of the Greasy Grouper (Epinephelus tauvina F.) and Brown-marbled grouper (E. fuscoguttatus) in Singapore. In Larvi'91Fish \& Crustacean Larviculture Symposium, P. Lavens, P. Sorgeloos, E. Jasper, and F. Ollevier (Eds) European Aquaculture Society, Special Publication, No.15: 321-322, Gent, Belgium.

DOI: 10.1111/j.1749-7345.1993.tb00015.x

Lindstrom, D.P. (1994) Early larval development of the endemic Hawaiian stream goby, Lentipes concolor. Pacific Scientific, 48, No. 2, 204 p.

Loosanoff, V.L. \& Davis, H.C. (1963) Rearing of bivalve molluscs. Advances in Marine Biology., 1:1-136. DOI: 10.1016/S0065-2881(08)60257-6

Lough, R.G. (1975) A revaluation of the combined effects of temperature and salinity on survival and growth of bivalve larvae using response surface techniques. Fishery Bulletin. U.S. Fisheries and Wildlife Service, 73: 8694.

McAndrew, B.J., Rana, K.J. \& Penman, D.J. (1993) Conservation and preservation of Genetic variation in aquatic organisms. In: Recent Advances in Aquaculture, J.F. Muir and R.J. Roberts (Editors), Blackwell Science, Oxford, 4: 295-336.

Myrina, B., Charlotte, C., Arnaud, H., Ismael, B., Claddie, Q, Virgile, Q. Caroline, F \& Suquet, M. (2015). Assessment of oocyte and trochophore quality in Pacific oyster, Crassostrea gigas. Aquaculture, 437:201-207. DOI: 10.1016/j.aquaculture.2014.11.025

Napolitano, G.E., MacDonald, B.A., Thompson, R.J \& Ackman, R.G. (1992) Lipid Composition of eggs and adductor muscle in giant scallops (Placopecten magellanicus) from different habitats. Marine Biology, 113: 71-76. DOI: 10.1007/BF00367640

Paredes, E., Adams, S.L., Tervit, H.R., Smith, J.F., McGowen, L.T., Gale, S.L. Morrish, J.R. \& Watts, E. (2012). Cryopreservation of Greenshell ${ }^{\mathrm{TM}}$ mussel (Perna canaliculus) trochophore larvae. Cryobiology, 65: 256-262. DOI: 10.1016/j.cryobiol.2012.07.078

Paredes, E., Bellas, J \& Adams, S.L. (2013). Comparative cryopreservation study of trochophore larvae from two species of bivalves: Pacific oyster (Crassostrea gigas) and blue mussel (Mytilus galloprovinciallis), Cryobiology, 65(3), 360 DOI: 10.1016/j.cryobiol.2013.08.007

Pollero, R.J., Re, M.E. \& Brenner, R.R. (1979) Seasonal changes of the lipids of the mollusks Chlamys tehuelcha. Comparative Biochemistry and Physiology, 64A: 257-263.

Sargent, J., Henderson, R.J. \& Tocher, D.R. (1989) The Lipids. In: Halver, J. (eds), Fish Nutrition. Academic Press, Inc., New York, pp. 153-218.

SAS Institute Inc. (1990) SAS Procedures Guide, version 6, third edition; SAS Language and Procedures: Introduction, version 6, first edition; SAS/STAT User's Guide, version 6, fourth edition, volume 1, ACECLUSFREQ and volume 2, CLM-VARCOMP. SAS ${ }^{\circledR}$, Institute Inc., Cary, NC, U.S.A. 
Sastry, A.N. (1979) Pelecypoda (excluding Ostreidae). In: A.C Geise and J.S Pearse (Editors), Reproduction of Marine Invertebrates, Vol. V., Academic Press, New York, pp. 113-292.

Scott, A.P. \& Baynes, S.M. (1980) A review of the biology, handling and storage of Salmonid spermatozoa. Journal of Fish Biology, 17: 707-739. DOI: 10.1111/j.1095-8649.1980.tb02804.x

Stoss, J. \& Holtz, W. (1983) Successful storage of chilled rainbow trout (Salmo gairdneri) spermatozoa for up to 34 days. Aquaculture, 31: 269-74.

Stottrup, J.G. \& Attramadal. Y. (1992) The influence of different rotifer and Artemia enrichment diets on growth, survival, and pigmentation in turbot (Scophthalmus maximus L.) larvae. Journal of World Aquaculture Society, 23: 307-316. DOI: 10.1111/j.1749-7345.1992.tb00794.x

Takatsu, T., Nakatani, T., Mutoh, T. \& Takahashi, T. (1995) Feeding habits of pacific cod Larvae and juveniles in Mutsu Bay, Japan. Fisheries Science, 61: $415-422$

Trider, J.D., Kurokura, H \& Kasahara, S. (1980) Influence of neutral lipid on seasonal variation of total lipid in oysters, Crassostrea virginica. Proceedings of the National Shellfisheries Association, 70: 112-118.

Tseng, W.Y. \& Chan, K.F. (1986) On the larval rearing of the white-spotted green grouper, Epinephelus amblycephalus (Bleeker), with a description of larval development. Journal of World Mariculture Society, 16: 114-126.

Tseng, W.Y. \& Poon, C.T. (1983) Hybridization of Epinephelus species Aquaculture, 34:177-182. DOI:10.1016/0044-8486(83)90302-2

Waldock, M.J. \& Holland, D.L. (1984) Fatty acid metabolism in young oysters, Crassosteria gigas: Polyunsaturated fatty acids. Lipids, 19: 332-336. DOI: $10.1007 / B F 02534783$
Watanabe, T. \& Ackman, R.G. (1974) Lipids and fatty acids of the American (Crassosterea virginica) and European flat (Ostrea edulis) oysters from a common habitat and after feeding with Dicrateria inornata or Isochrysis galbana. Journal of the Fisheries Board of Canada, 31: 403-409. DOI: 10.1139/774-068

Watanabe, T., Kitajima, C. \& Fujita, S. (1983) Nutritional values of live organisms used in Japan for mass production of fish: a review. Aquaculture, 34: 115-143. DOI: 10.1016/0044-8486(83)90296-X

Watanabe, W.O., Ellis, S.C., Ellis, E.P., Lopez, V.G., Bass, P., Ginazo, J. \& Moriwake, A. (1996) Evaluation of first-feeding Regimes for larval Nassau Grouper Epinephelus striatus and preliminary pilot-scale culture through metamorphosis. Journal of the World Aquaculture Society, 27, No. 3:323331. DOI: $10.1111 / j .1749-7345.1996 . t b 00615 . x$

Whyte, J.N.C, Bourne, N. \& Hodgson, C.A. (1987) Assessment of biochemical composition and energy reserves in the scallop Patinopecten yessoences. Journal of Experimental Marine Biology and Ecology, 113:113-124.

Whyte, J.N.C., Bourne, N. \& Ginther, N.G. (1990) Biochemical and energy changes during embryogenesis in the rock scallop Crassadoma gigentia. Marine Biology, 106: 239-244.

DOI: $10.1007 / B F 01314806$

Whyte, J.N.C., Bourne, N. \& Ginther, N.G. (1991) Depletion of nutrient reserves during embryogenesis in the scallop Patinopecten yessoensis (Jay). Journal of Experimental Marine Biology and Ecology, 149: 67-79. DOI:10.1016/0022-0981(91)90117-F 